\title{
Review on In Vitro Propagation of Sugarcane to Advance the Value of Tissue culture
}

\author{
Belete Getnet* \\ Ethiopian Sugar Corporation, Research and Training Division, Ethiopia
}

Submission: March 03, 2017; Published: April 05, 2017

"Corresponding author: Belete Getnet, Ethiopian Sugar Corporation, Research and Training Division, Variety Development Research Directorate, Biotechnology Research Team, Wonji, East Shoa, EthiopiaEmail: bgetnet704@gmail.com

\begin{abstract}
Sugar cane is an economically important agro industrial crop and propagated conventionally by sets, however, low propagation rates, its time demand, huge land requirement and potential transmission of pathogens through seed cane from generation to generation are the major limitations of conventional propagation. The ultimate objective of this review is the effect of propagation method for increasing yield by reducing varietal deterioration. In vitro propagation is the best alternative to overcome such limitations to produce disease free and sufficient amount of planting material. Micro propagation is however a very sensitive technique, which requires aseptic condition in each stages (0-4) namely mother plant establishment, initiation and establishment of aseptic culture, multiplication, rooting, and acclimatization. This can be concluded that knowledge is needed regarding sensitivity of work for contamination and the economical importance of tissue culture to support the conventional propagation. This will allow the sugar industry estates to produce sufficient planting material within short period of time and cost effective.
\end{abstract}

\section{Introduction}

Sugarcane is a perennial grass family crop that normally reproduces through sexual and asexual modes. It reproduces asexually by three or two buds stem cutting called sets, and innovative approaches of in vitro propagation by taking parts of it such as shoot tip, apical meristem, axillary shoot, bud and leaf. It also reproduces through seed propagation via flower (fuzz), which is used for breeding purposes. Sugarcane varieties are developed at sugarcane breeding institutions of the world through screening of large number seedlings raised from fuzz (true seeds) obtained from through breeding. Currently in Ethiopia, the breeding program involves only the import of fuzz and selection of exotic lines. However, most of the time the flower of sugarcane is not viable, and the reason behind this might be highly variable. This variation source is not required to maintain continuity of the variety to be stable for commercial propagation rather than using for the variety development.

\section{Conventional propagation}

Sugarcane is propagated commercially by vegetative method, which involves the planting of the stem cuttings of premature cane about 8 to 12 months old grown with special care are recommended for seed cane [1]. The seed cane that is used as planting material may be either whole stalks or stalks` cut up in shorter segments called sets [2]. The growth of sugarcane has different phases: emergency, tillering, stalk growth, and maturation. The germination is a critical event in the plant life to assure a good harvest. It is initially dependent on the set nutrients and water till developing its own root system for three weeks under proper conditions, though, the initial growth of sugarcane is influenced by several internal and external factors such as set age, cultivar, sets nutrients, temperature, soil aeration; sets position on the stalk and humidity [1].

A cane sett is the main conventionally propagation system for sugarcane growing countries in the world, including Africa. In some instances, the buds scooped out of the cane using a bud-chipping machine or knives are used for raising the seed nursery [3]. These seed canes involve a three bud system after treating with hot water or aerated steam therapy to kill pathogens and pests harboring the seed pieces and treating the sets with a fungicide. The treated sets planted in seed nurseries are used to raise primary seed which is used as planting material to grow a foundation seed and the foundation seed in turn is used to raise the certified seed nurseries. Higher seed rate of 75,000 two-bud sets per hectare is needed for raising breeder's seed to compensate for germination loss due to heat therapy [3]. 
In addition, one bud shoot produces four to five shoots in a year [4] and 1ha of seed cane is only sufficient to plant 10 ha commercial fields (1:10) in 7-10 months [5]. Thus, The newly released varieties take 6-10years to produce enough quantity of initial seed material for the required vast area [6,7], while its seed propagation rate ranging from 1:7 to 1:10 [8,9]. However, the seed accumulates diseases and pests during several cycles of field production. In general, nonavailability of quality and true to type planting material of newly released varieties is a major constraint in their quick adoption for commercial use, and improving sugarcane productivity. Even well adopted commercial varieties cultivation required availability of quality seed to ensure better cane yield, sugar yield, pathogens and pest-free crop [10]. Further, traditional method of cultivation using three-budded set requires large quantity of seed, which is costly, time consuming and land demanding [11].

Therefore, development of tissue culture technology for rapid multiplication of disease-free planting material has been an important step towards sufficient, true to type and quality seed production in sugarcane. Australia, India and the Philippines in the Asia-Pacific region have already applied this technology for commercial seed production and the benefits have become evident through rapid propagation and distribution of elite varieties and increased sugarcane production [3]. The experiences of these countries would be of considerable benefit to all those who are in the process of adopting micropropagation for their seed production programs like Ethiopia and others.

\section{In vitro propagation}

Conventional propagation of sugarcane suffered from low propagation rates, expensive labour, time consuming and potential transmission of pathogens through seedcane from generation to generation, which limits the efficiency of this method [12]. This long time taken of propagation causes a major bottleneck in commercial propagation and breeding programmers [13]. Thus, the growing demand of newly released varieties could not be fulfilled by only conventional propagation methods.

Therefore, application of plant tissue culture techniques provides an alternative method for multiplication and improvement of sugarcane [14]. Plant tissue culture offers the best methodology through micro propagation of sugarcane for quality and phytosanitary planting material at a faster rate in a shorter period. Tissue culture can increase the propagation potential by 20-35 times [15]. About 18, 520 plants, produced from a single shoot through micro propagation, were required as compared to 8.8 tons of cane seed in conventional methods for planting in one hectare. Thus, multiplication ratio was 100-150 times using tissue culture plants as compared to 11-12 using conventional cane sets, leading to drastic reduction in seed cane requirement [16]. Kuar \& Sandhu [17] showed the shoot multiplication rates were ranged from 4 to 25 fold in $\mathrm{CoPb} 91$ and $\mathrm{CoJ} 83$ cultivars, respectively and the complete plantlets were produced in 157 days with $97 \%$ survival rate. The fidelity of this protocol for agri-business industry was tested by producing approximately 0.1 million saleable HTM sugarcane plantlets in a small-scale $(150 \mathrm{~m} 2)$ tissue culture unit.

In addition, plants can be disease indexed and healthy material multiplied in half time compared to the conventional route [18]. Hence, methods of more efficient regeneration protocol for propagation have been developed through micro propagation [3]. Currently, it is the only realistic means of achieving rapid, large-scale production of disease-free seed canes of newly developed varieties in order to speed up the breeding and commercialization process in sugarcane. Further, it is an important tool for the production of thousands of genetically uniform and safe plantlets, and its usefulness in germplasm storage [4]. Khan et al. [19] stated that in vitro propagation produce millions of plantlets from single shoot tip within a short period in contrast to conventional method where one bud produces, 4-5 shoots. Lee [20] and Lal et al. [21] produced around 10,000 identical plantlets in about 3-4 months and 75600 shoots from a single shoot apex explants in a period of about 5.5 months.

Hendre et al. [22] and Biradar et al. [5] estimated that it is possible to produce some 260,000 shoots in four months and $2 \times 10^{8}$ plantlets in a year over $4-5$ weeks sub culturing cycles from single shoot tips of seedcane respectively. Moreover, the micro propagated plants (CV. Co 83) grown in the field had up to $44.96 \%$ more canes/plots and up to $22.9 \%$ greater cane yield/plot than plants conventionally propagated from three-budded sets [23]. Ben sheikh et al. [24] also stated that gross yield obtained from in vitro multiplication derived plantlets seedcane source becomes over than their source plants.

\section{Stock/mother plant establishment}

A pre-propagation stage requires proper maintenance of the mother plants in the greenhouse under disease and insect free conditions with minimal dust. Collection of plant materials for in vitro propagation should be treated using appropriate pretreatment via, fungicides and bactericides to minimize contamination in the in vitro cultures [25]. To enhance the probability of success, the mother plant should be grown under optimal conditions in the greenhouse to maintain the crop physiology normal besides minimizing contamination in vitro [26].

Explants taken from field plants have problem of microbial contamination, as total sterilization of these explants is generally difficult. Moreover, physiological status of source plant also influences the response of explants [27]. As a result, the explants are then taken from greenhouse grown stock plants give rise to better results for in vitro propagation study as the load of contaminants is minimal compared to the ones grown in field conditions [28]. There are huge variations regarding in vitro culture response of explants excised from plants grown in field condition depending on weather conditions during the year, hence, the best results obtained from explants excised from in vitro grown seedlings [27]. About 85-95\% shoots tip cultures reached successfully to the shoot proliferation. 


\section{Apical/axillary meristem culture}

Plant tissue cultures are initiated from tiny pieces, called explants, taken from any part of a plant. Practically all parts of a plant have been used successfully as sources of explants. Plant segments used in tissue culture as explants are shoot tip, apical meristem, axillary bud, root tip, leaf, flower, ovule, cotyledon and hypocotyls. In sugarcane, shoot tip from 1-2 cm [24,29-31], apical meristem from 1-6mm [32-35], leaf roll disk [4,36-38]. These explants form direct and indirect organs, embryos, though, shoot tips and meristems give successful results for direct shoot regeneration [39]. Apical meristem is a small group of cells that develops to shoot, and communicates signals to the rest of the plant [40]. Apical Meristem tips are perhaps the most popular source of explants to tissue cultures $[7,41,42]$. Because the apical meristem is the origin of the shoot, it has four functions; initiating new organs and tissues, communicating signals to the rest of the plant, and maintaining itself as a formative region [43].

It is the most distal to outer portion of the shoot and comprises two groups of cells: the initial/source cells and the cells that are progenitors for tissues and lateral organs or it is a region just proximal to the meristem where lateral organ primordial are formed. Moreover, in vitro propagation through apical and axillary meristem shoot is the most common technique in India and Australia for commercial mass production [3]. This is due to the cells of apical and axillary meristems that are uniformly diploid and least susceptible to genotype changes, ensures genetic stability of the clones [44]. Eight sugarcane clones plantlet derived using meristem culture method were phenotypic ally uniform and $4 \mathrm{~mm}$ size of meristem was the most suitable for establishment of culture while meristems were treated with a solution of ascorbic acid (100mg/l)+citric acid (150mg/l) for 10-15 minutes, phenolics could be controlled [45].

\section{Size of explants}

The sizes of explants were determined by the purpose of the experiment and the efficiency of regenerating multiple shoots. Virus free in vitro derived plantlets were successfully regenerated from 0.07 to $2 \mathrm{~mm}$ meristem size $[42,46,47]$. Apical meristem and shoot tip having 0.03 to $2 \mathrm{~cm}$ size [29,33,35 48,49] used for genetically uniform and potential in vitro propagation across the world. However, the culture of small meristems exhibits lower rates of survival and regeneration during shoot initiation than larger blocks of meristem. This happens probably because meristems having larger sizes provide more amounts of readily available nutrients that require for initiation of shoot primordial than those of smaller sizes [49]. They obtained higher regeneration potential at $4 \mathrm{~mm}$ size (60\%) than in smaller ones at size of 2 and $3 \mathrm{~mm}(40 \%)$ during initiation.

Ali et al. [48] also obtained high regeneration of apical meristems at $4 \mathrm{~mm}(100 \%)$ for two genotypes. Ali et al. [33] obtained $100 \%$ survival with $90 \%$ regeneration potential at $3 \mathrm{~mm}$ size within 12 days, and the time for shoot formation was increased by decreasing the size of the meristem. However, when the explants became extremely large, contaminations are highly serious [49]. In contrary, successful results from highly small explants are reported in previous works. Parmessur et al. [46] reported Larger meristems $(>1 \mathrm{~mm})$ are likely to be died, whereas smaller ones $(<0.3 \mathrm{~mm})$ are unlikely to develop into plantlets, and the success resides in the ability to isolate the meristematic with one or two leaf primordial. Jahangir et al. [42] reported successfully regenerates of apical meristem at $0.07 \mathrm{~mm}$ length size for disease free and rapid mass production of sugarcane cultivars. Generally, the efficient genetically stable in vitro propagation to produce potential multiple shoots, 4-6mm size shoot apical meristem was the best in sugar cane [35].

\section{Explants surface sterilization and shoot establishments}

Even though it is not a crucial stage of micro propagation, shoot initiation and establishment is the most difficult step due to regeneration potential and contamination especially grass family crops like sugarcane and other woody trees. Contamination in tissue culture can originate from two sources, both on the surface and in the tissues of explants or through faulty procedures in the laboratory. Establishing of tissue culture depends on the explants used, surface and endophytic microorganisms. In meristem culture, most organisms would be eliminated due to its small size, whereas in large explants (leaf, stem etc), most if not all microorganisms in the tissues may be carried over [26]. To avoid contamination, the explant has to be washed and cleaned up prior to surface sterilization by using liquid soap, commercial detergent, kocide (antifungal), tween 20 or 80 etc with tap water.

Although different sterilization agents such as $\mathrm{Ca}(\mathrm{OCl})_{2}, \mathrm{H}_{2} \mathrm{O}_{2}$, $\mathrm{NaOCl}, \mathrm{HgCl}_{2}$ and ethanol can be used for surface sterilization, ethanol, $\mathrm{NaOCl}$ and $\mathrm{HgCl}_{2}$ are the most common frequently used agents. Tiwari et al. [50] studied four sterilization agents (EtOH, $\mathrm{NaOCl}, \mathrm{HgCl}_{2}$ and $\mathrm{H}_{2} \mathrm{O}_{2}$ ) in combination and alone using leaf sheath explants of two fields grown sugarcane varieties. The authors showed that the use of only one sterilizing agent is not successful, and $\mathrm{HgCl}_{2}(0.1 \%)$ for $5 \mathrm{~min}$ and $\mathrm{Et} \mathrm{OH}(90 \%)$ for $10 \mathrm{~min}$ was the best along with prior washing and surface sterilization with tween 20 and bavistin. Benisheikh et al. [24] used 70\% ethanol for 30 second to one-minute using shoot tip explants, followed by $0.1 \% \mathrm{HgCl}_{2}$ for another five minutes. However, $\mathrm{HgCl}_{2}$ is highly carcinogenic, and toxic to the plant cells entering through the xylem during sterilization. Hence, other safer alternative sterilization methods are developed to avoid this risk through replacing $\mathrm{HgCl}_{2}$ by $\mathrm{NaOCl}$ and ethanol [47]. Cheong et al. [51] used 70\% ethanol for surface sterilization of apical meristem and auxiliary bud. Khan et al. [4] reported 50\% Clorox (Berekina, 5.25\% active chlorine) for 30 minutes then put in 70\% ethanol for 45 minutes. Mekonnen et al. [52] reported surface sterilization with $25 \%$ Berekina (5\% active chlorine) for $25 \mathrm{~min}$ exposure time is optimal for sugarcane shoot tip decontamination, and this treatment could replace $0.1 \%$ mercury chloride for 10 minutes. Generally, shoot regeneration in several tropical plant species has been studied and found satisfactory efficiency (82-93\%) for maize, citrus species, Brassica spp. and 
winged been except sugarcane (53\%) which was thought to be due to the presence of surface hairs on the leaves and stalks [53].

\section{Adventitious shoot proliferation}

The multiplications of shoots are a crucial stage in the propagation of any species for commercial exploitation and the most rapid rates are required. The most common additives to standard media are cytokines usually as BAP, BA and Kinetin alone or with combination of low amount auxins like NAA, IBA and IAA. Typically, the same medium and environmental conditions are used for both shoot initiation and multiplication [54]. The rate of shoot multiplication mainly depends on a number of factors. These are type and combination of plant growth regulators, explants type, culture medium composition, and genotype. Jagadeesh et al. [55] showed that high ratio of cytokinin and auxins was essential and better for production of adventitious shoots rather than cytokinin alone in sugarcane. The authors found the highest multiple shoot on MS medium with 3mg/l BAP+2mg/l IAA+2mg/l Kin.

Bhor and Mungse [56] obtained the maximum number of shoots (9.8 in Co-86032 and 8.1 in CoM-88121) on MS medium+1.0mg/I BAP+0.5mg/l NAA. Koy and Kabir [57] obtained the maximum of 17.2 shoots and 7.2 shoot length on $\mathrm{MS}+1.5 \mathrm{mg} / \mathrm{l}$ BA with $0.5 \mathrm{mg} / \mathrm{l}$ NAA in Isd32 genotype. Abdu et al. [58] reported the highest number, length and vigor of shoots in all the genotypes on MS media containing 1.0 and $1.5 \mathrm{mg} / \mathrm{L} \mathrm{BA}$ with $0.2 \mathrm{mg} / \mathrm{L} \mathrm{NAA}$. Gopitha et al. [59] also achieved best regeneration of shoots on MS medium fortified with BAP $1.0 \mathrm{mg} / \mathrm{L}$ and IBA $0.5 \mathrm{mg} / \mathrm{L}$. A maximum of 24 and 29 shoots per bud for cv. Mex 68-P23 and cv. MY 5514 respectively in six weeks on $2 \mathrm{mg} / \mathrm{l}$ Kin with $1 \mathrm{mg} / \mathrm{l}$ NAA were reported [60]. Mamun et al. [61] obtained best shoots for Isd-28 and Isd-29 on MS medium fortified with $1.5 \mathrm{mg} / \mathrm{l} \mathrm{BA}$ and $0.5 \mathrm{mg} / \mathrm{l} \mathrm{NAA}$. Best multiplication on $0.5 \mathrm{mg} / \mathrm{l}$ BAP with $0.5 \mathrm{mg} / \mathrm{l} \mathrm{NAA}$ and $15 \%$ CW was also obtained [62]. In addition, Yadav et al. [63] reported best response of multiplication on MS medium with BAP, Kin and NAA $(0.5 \mathrm{mg} / \mathrm{l}$ each). Sahoo et al. [64] obtained multiple shoots from meristems on MS medium with 1.0mg/l BA, $0.5 \mathrm{mg} / \mathrm{l}$ Kin and $0.25 \mathrm{mg} / \mathrm{l}$ NAA.

Furthermore, there are also many reports in cytokinin combinations. Khan et al. [4] reported the optimum multiplication for var. HSF-240, CP-77-400 and CPF-237 at 1.5mg/l BAP with $0.5 \mathrm{mg} / \mathrm{l} \mathrm{Kin}, 1.0 \mathrm{mg} / \mathrm{l}$ BAP with $0.5 \mathrm{mg} / \mathrm{l} \mathrm{Kin}$, and $1.0 \mathrm{mg} / \mathrm{l} \mathrm{BAP} \mathrm{with}$ $0.1 \mathrm{mg} / \mathrm{l} \mathrm{Kin}$. Abbas et al. [35] reported the optimum multiplication for HSF-240, CP-77-400 SPF-213, HSF-242 and CP-43-33 genotypes on MS with $1.5 \mathrm{mg} / \mathrm{l} \mathrm{BAP}$ and $0.5 \mathrm{mg} / \mathrm{l} \mathrm{Kin}, 0.5 \mathrm{mg} / \mathrm{l} \mathrm{BAP}$ and $1.0 \mathrm{mg} / \mathrm{l}$ Kin, $1.5 \mathrm{mg} / \mathrm{l}$ BAP and $0.1 \mathrm{mg} / \mathrm{l} \mathrm{Kin}, 1.5 \mathrm{mg} / \mathrm{l}$ BAP and $0.1 \mathrm{mg} / \mathrm{l}$ Kin, and $1.0 \mathrm{mg} / \mathrm{l}$ BAP and $0.1 \mathrm{mg} / \mathrm{l}$ Kin respectively. Ali et al. [33] obtained maximum shoot multiplication in CP 77400 and BL-4, found 29 shoots on MS medium with $1.0 \mathrm{mg} / \mathrm{l} \mathrm{BAP,} \mathrm{and} 0.25 \mathrm{mg} / \mathrm{l}$ BAP and Kin respectively.

\section{Rooting}

The success of in vitro propagation relies on efficient rooting in regenerated shoot and their subsequent acclimatization. Once the sufficient numbers of shoots have been generated, portion of explants that contains one or more shoots could be transferred to a medium that contains higher concentration of auxins, resulting in root formation. The initiation of roots is easily achieved in some species by reducing the cytokinin level [38] or on MS medium with or without the addition of extra root promoting auxins [11]. In sugarcane, auxins especially IBA from $0.5-3 \mathrm{mg} / \mathrm{l}[4,54]$ and NAA from $0.5-7 \mathrm{mg} / \mathrm{l}[38,41,65]$ alone or in combination are the most common used auxins for rooting.

Most of researchers reported in vitro regenerated roots of sugarcane shoots on MS basal medium fortified with auxins $[47,64,65]$. Khan et al. [4] reported vigorous root development on MS medium containing $6 \%$ table sucrose $+1 \mathrm{mg} / \mathrm{l}$ IBA among the combinations used. However, the MS medium without growth regulators promoted rooting in more than $90 \%$ of two cultivars after 30 days of culture $[11,66]$. In addition to the presence and absence of growth regulators, rooting was greatly dependent on the strength of MS medium in various plant species. Jagadeesh et al. [55] reported that half MS media were more responsive than full MS medium for rooting of sugarcane. This resulted in $77.78 \%$ of root inducing shoots from 14.3 days of shoots inoculated on $1 / 2$ MS+6 mg/l NAA medium. Sahoo et al. [64] reported that rooting of shoots was achieved on half MS basal medium with 2mg/l NAA plus $6 \%$ sucrose. Tiwari et al. [49] obtained $100 \%$ rooted shoots on $1 / 2$ MS medium supplemented with $50 \mathrm{~g} / \mathrm{l}$ sucrose and $5.0 \mathrm{mg} / \mathrm{l}$ NAA at pH 6.0 within two weeks. Rooting (85-92\%) was induced by transferring shoots on $1 / 2$ MS medium supplemented with $2 \mathrm{mg} / \mathrm{l}$ NAA and $1.0 \mathrm{mg} / \mathrm{l}$ IBA [67].

Rooting was highly influenced by the different types and concentrations of auxins used. Even if there also results reported on the IBA and IAA, NAA was the most efficient auxins for root initiation of sugarcane in vitro propagation [4,54]. Jagadeesh et al. [55] reported NAA was better than IBA either alone or in combination with other hormones for rooting of sugarcane. In general, many researchers reported that $5 \mathrm{mg} / \mathrm{l}$ NAA was good for rooting $[16,45,63,65]$, but more than $5 \mathrm{mg} / \mathrm{l}$ NAA inhibits rooting [5]. In contrary, many researchers obtained best rooting at lower concentration of NAA from $0.5-3 \mathrm{mg} / \mathrm{l}[38,64,68,69]$.

\section{Acclimatization of in vitro regenerates}

Acclimatization of in vitro propagated plantlets to the ex vitro environment is a critical step for successful propagation. It is ultimately depending on their ability to withstand the conditions transferring from in vitro to ex vitro because the in vitro environments are highly conducive than ex vitro environment. In sugarcane, successful acclimatization can be possible by taking in vitro shoots at two different stages of the plantlets. Either this is when in vitro regenerated plantlets have an optimum shoot/root ratio [42,55] or after optimum shoot formation but before rooting on in vitro medium what is called ex-vitro rooting. Furthermore, the acclimatization of in vitro regenerated shoots can be achieved efficiently if the plants are initially maintained with high humidity conditions. Tiwari et al. [49] reported that over 6000 rooted 
shoots were transferred to greenhouse for hardening, of which $94 \%$ of the plantlets survived. Yadav et al. [63] reported that $90 \%$ survival rate was recorded in the greenhouse condition. Similarly, easily acclimatized sugarcane plantlets using soil as substrate and the initial plantlets cultured in mist chamber condition by adding fertilization weekly was demonstrated $[11,70]$.

The media compositions with its ratio also play a vital role to increase survivality of plantlets. Ather et al. [71] reported that in vitro grown plantlets survived successfully with the rate of $96 \%$ after four weeks when farmyard manure was used with garden soil in the ratio of 1:4 as a potting mixture. Jagadeesh et al. [55] reported that the treatment combination of vermicompost: soil: sand (1:1:1) gave the highest survival percentage of $75 \%$, followed by the treatment combination of press mud: soil: sand (1:1:1) which produced 50\% survival. Dibax et al. [66] also reported that use of composed substrate of vermiculite + MS salts was effective for acclimatization. In addition, the type of media used such as liquid and semisolid are also a highly important detrimental factor. Snyman et al. [72] obtained approximately 18,000 plants/leaf roll by using temporary immersion in vitro culture in 12 weeks when compared with approximately 2000 plants/leaf roll produced on semi-solid medium. However, due to hyperhydricity, only $\sim 34 \%$ of the plants produced in RITA $®$ were survived in acclimatization.

\section{Summary and Future Line}

There is a high transmission and incidence of disease through stem cutting seedcane grown plants. This is particularly true in Ethiopia since yield losses can be increased due to disease under suitable environmental conditions in mineral soils. Using in vitro propagation derived plantlets decrease diseases transmission like smut, yellow leaf virus, Leaf scald, mosaic virus, ratoon stunting disease and others that spread through generation and sugar estates in the case of seedcane with subsequent cost reduction of disease control and increasing yield. In line with this, healthy seed cane supply is the lifeline in the productivity and profitability of sugarcane, hence for the sustainability of sugar industry; all the Ethiopian sugar estates/projects should be used tissue culture derived sugarcane planting materials.

\section{References}

1. Sime M (2013) The effect of different cane portions on sprouting, growth and yield of sugarcane (Saccharum spp L.). International Journal of Science Research Publication 3(1): 338-341.

2. Garside A, Braunack M (2001) The sugar cane cropping system. In: Hogarth M, Allsopp P (Eds.), Manual of cane growing. Bureau of sugar Experiment stations Indooroopilly, Australia, pp. 127-139.

3. Jalaja N, Neelamathi D, Sreenivasan T (2008) Micro propagation for quality seed production in sugarcane in Asia and the Pacific. Food and Agric Organization of the UN, sugarcane pub, USA, pp. 13-60.

4. Khan I, Dahot M, Seema N, Yasmeen A, Naqvi M, et al. (2009) Direct regeneration of sugarcane plantlets: a tool to unravel genetic heterogeneity. Pakistan Journal Botany 41(2): 797-814.

5. Biradar S, Biradar D, Patil VC, Patil S, Kambar N, et al. (2009) In vitro plant regeneration using shoot tip culture in commercial cultivar of sugarcane. Karnataka Journal of Agriculture and Science 22(1): 21-24.
6. Sengar AS, Thind KS, Kumar B, Pallavi M, Gosal SS, et al. (2009) In vitro selection at cellular level for red rot resistance in sugarcane (Saccharum sp.). Plant growth regulation 58(2): 201-209.

7. Sughra M, Altaf S, Rafique R, Umar D (2014) In vitro regenerability of different sugarcane (saccharum officinarum l.) Varieties through shoot tip culture. Pakistan Journal of Biotechnology 11(1): 13-23.

8. Sood N, Gupta P, Srivastava R, Gosal S (2006) Comparative studies on field performance of micro propagated and conventionally propagated sugarcane plants. Plant Tissue Cult \& Biotech 16(1): 25-29.

9. Dash M, Mishra P, Mohapatra D (2011) Mass propagation via shoot tip culture and detection of genetic variability of Saccharum officinarum clones using biochemical markers. Asian Journal of Biotechnology 3(5): 378-387.

10. Flynn J, Powell G, Perdomo R, Montes G, Quebedeaux K, et al. (2005) Comparison of Sugarcane disease Incidence and Yield of Field-Run, Heat-Treated, and tissue- Culture Based Seedcane. J Amer Soc Sugar Cane Technol Vol.25.

11. Singh N, Kumar A, Garg G (2006) Genotype dependent influence of phytohormones combination and sub culturing on micro propagation of sugarcane varieties. Indian Journal of Biotechnology 5(1): 99-106.

12. Lakshmanan P, Geijskes R, Wang L, Smith G, Elliott A, et al. (2006) Developmental and hormonal regulation of direct shoot organogenesis and somatic embryogenesis in sugarcane (Saccharum spp. interspecific hybrids) leaf culture. Plant Cell Rep 25(10): 1007-1015.

13. Siddiqui S, Khan I, Khatri A, Nizamani G (1994) Rapid multiplication of sugarcane through micro propagation. Pakistan Journal of Agricultural Research 15(1): 134-136.

14. Sengar K, Sengar R, Garg SK (2011) The effect of in vitro environmental conditions on some sugarcane varieties for micro propagation. Africa Journal of Biotechnology 10(75): 17122-17126.

15. Snyman S, Meyer G, Richards J, Ramgareeb S, Huckett B, et al. (2006) Refining the application of direct embryogenesis in sugarcane: effect of the developmental phase of leaf disc explants and the timing of DNA transfer on transformation efficiency. Plant cell reports 25(10): 10161023.

16. Sandhu S, Gosal S, Singh K, Cheema G, Meeta M, et al. (2009) Field performance of micro propagated plants and potential of seed cane for stalk yield and quality in sugarcane. Sugar Technology 11(1): 34-38.

17. Kuar A, Sandhu S (2014) High throughput in vitro micro propagation of sugarcane (Saccharum officinarum L.) from spindle leaf roll segments: Cost analysis for agri-business industry. Plant Cell Tissue Organ Culture 120(1): 339-350.

18. Snyman S, Antwerpen T, Richards J, Rutherford R, (2007) Micro propagation by direct somatic embryogenesis. International Society Sugar Cane Technology pp. 943-947.

19. Khan I, Dahot U, Yasmin S, Khatri A, Seema N, et al. (2006) Effect of sucrose and growth regulators on the micropropagation of sugarcane clones. Pakistan Journal of Botany 38(4): 961-967.

20. Lee G (1987) Micro propagation of sugarcane (Saccharum spp.). Plant Cell Tissue and Organ Culture 10(1): 47-55.

21. Lai N, Krishna R (1996) Yield comparison in sugarcane crop raised from conventional and mericlone derived seed cane. Indian Sugar 47(8): 617-621.

22. Hendre R, Iyer R, Kotwal M, Khuspe S, Mascarenhas A, et al. (1983) Rapid multiplication of sugarcane by tissue culture. Sugarcane 1(5): 5-8.

23. Gosal S, Thind K, Dhaliwal H (1998) Micropropagation of sugarcane an efficient protocol for commercial plant production. Crop Improvement 25(2): 167-171. 
24. Benisheikh A, Mala M, Ahmadu U, Fatima B, Zainab, M, et al. (2012) Virus free plantlets production of sugar (Saccharum officinarum L.) through in vitro micropropagation of shoot tip culture. Con. J Biol Sci 5(1): 42-46

25. Ahloowalia B, Savangikar V, Prakash J, Savangikar C (2004) Low cost options for tissue culture technology in developing countries. International Atomic Energy Agency 1384: 112.

26. Cassells A (2005) Problems in tissue culture: culture contamination. In: micro propagation. Springer, Netherlands, pp. 31-44.

27. Rakesh S, Kaur S, Garg S (2011) Role of tissue culture technique in high sugarcane production. International Research Journal Life Science Leaflets 21(2): 1008-1017.

28. Tiwari A, Tripathi S, Lal M, Mishra S (2012) Screening of some chemical disinfectants for media sterilization during in vitro micro propagation of sugarcane. Sugar Tech 14(4): 364-369.

29. Tolera B, Diro M, Belew D (2014) Response of sugarcane (Saccharum officinarum L.) Varieties to BAP and kinetin on in vitro shoot multiplication. International Journal of Innovative Research and Development 3(5): 694-697.

30. Shimelis D, Bantte K, Feyissa T (2014) Interaction effects of 6-benzylaminopurine and kinetin on in vitro shoot multiplication of two sugarcane (Saccharum officinarum L.) genotypes. Advance Crop Science and Technology 2(143): 1-5.

31. Mekonnen T, Diro M, Sharma M, Tadesse N (2014) Protocol optimization for in vitro mass propagation of two sugarcane (Saccharum officinarum L.) clones grown in Ethiopia. Africa Journal of Biotechnology 13(12): 1358-1368.

32. Ali A, Naz S, Iqbal J (2007) Effect of different explants and media compositions for efficient somatic embryogenesis in sugarcane (Saccharum officinarum). Pak J Bot 39(6): 1961-1977.

33. Ali A, Naz S, Siddiqui F, Iqbal J (2008) An efficient protocol for large scale production of sugarcane through micropropagation. Pakistan Journal of Botany 40(1): 139-149.

34. Khan S, Rashid H, Chaudhary M, Afroz A (2008) Rapid micro propagation of three elite Sugarcane (Saccharum officinarum L.) varieties by shoot tip culture. Africa Journal of Biotechnology 7(13): 2174-2180.

35. Abbas S, Gardazi S, Khan S, Abbas M, Shahzad S, et al. (2013) Hormonal effect on shoot multiplication in sugarcane genotypes. International Journal of Science and Research 4(7): 995-1001.

36. Ali S, Khan M, Iqbal J (2012) In vitro direct plant regeneration from cultured young leaf segments of sugarcane (Saccharum officinarum L.) Journal of Animal and Plant Science 22(4): 1107-1112.

37. Pandey N, Singh P, Singh K, Sharma ML (2012) Early assessment of genetic fidelity in sugarcane (Saccharum officinarum $L$ ) plantlets regenerated through direct organogenesis with RAPD and SSR markers. Australia Journal of Crop Science 6(4): 618-624.

38. Nawaz M, Ullah I, Iqbal N, Iqbal Z (2013) Improving in vitro leaf disk regeneration system of sugarcane (Saccharum officinarum L.) with concurrent shoot/root induction from somatic embryos. Turk Journal of Biology 37(6): 726-732.

39. Yildiz M (2012) The prerequisite of the success in plant tissue culture: High frequency shoots regeneration. Intech Open Access Publisher pp.1-28.

40. Medford J (1992) Vegetative apical meristems. The plant cellular American Society plant physiology 4(9): 1029-1039.

41. Adilakshmi D, Jayachandra K, Bebi P (2014) In vitro meristem tip culture of sugarcane varieties 96A3 and Co6907. International Journal of Advance Life Science 7(1): 148-154
42. Jahangir G, Nasir I, Iqbal M (2014) Disease free and rapid mass production of sugarcane cultivars. Advance Life Science 1(3): 171-180.

43. Viet B (2009) Hormone mediated regulation of the shoot apical meristem. Plant Mol Biol 69(4): 397-408.

44. Kuar K (2014) In vitro mass cloning of Dianthus chinensisâ a horticultural important plant. MSc thesis, Department of Biotechnology, Thapar University Patiala, India, pp. 85.

45. Karim MZ, Alam R, Baksha R, Paul SK, Hossain MA, et al. (2002) Micropropagation of two sugarcane (Saccharum officinarum) varieties from callus culture. Journal of biological science 2(10): 682-685.

46. Parmessurv Y, Aljanabi S, Saumtally S, Saumtally A (2002) Sugarcane yellow leaf virus and sugarcane yellows phytoplasma: elimination by tissue culture. Plant Pathology 51(5): 561-566.

47. Tiwari P, Sawant R, Dalvi S, Nikam A, Kawar P, et al. (2008) An assessment of somaclonal variation in micropropagated plants of sugarcane by RAPD markers. Sugar Tech 10(2): 124-127.

48. Ali A, Naz S, Siddiqui F, Iqbal J (2008) An efficient protocol for large scale production of sugarcane through micropropagation. Pakistan Journal of Botany 40(1): 139-149.

49. Tiwari A, Tripathi S, Lal M, Sharma M, Chiemsombat P, et al. (2011) Elimination of sugarcane grassy shoot disease through apical meristem culture. Archives of Physiopathology and Plant Protection 44(20): 1942-1948.

50. Tiwari S, Arya A, Kumar S (2012) Standardizing sterilization protocol and establishment of callus culture of sugarcane for enhanced plant regeneration in vitro. Research Journal of Botany 7(1): 1-7.

51. Cheong E, Mock R, Li R (2012) Elimination of five viruses from sugarcane using in vitro culture of axillary buds and apical meristems. Plant Cell Tissue Organ Culture 109(3): 439-445.

52. Mekonnen T, Diro M, Sharma M (2013) An alternative safer and cost effective surface sterilization method for sugarcane (Saccharum officinarum L.) explants. Africa Journal of Biotechnology 12(44): 62826286.

53. Kumari R, Verma D (2001) Development of micropropagation protocol for sugarcane. Agricultural Revolution 22(2): 87-94.

54. Singh R (2003) Tissue culture studies of sugarcane M Sc thesis: Thapar Institute of Engineering and Technology. Patiala, India pp. 1-62.

55. Jagadeesh B, Kumar M, Shekhar M, Udhakar P (2011) Amenability of the sugarcane variety 2005 t 16 to shoot tip culture. Journal of Sugarcane Research 1(2): 75-77.

56. Bhor T, Mungse H (2005) In vitro micro propagation studies in sugarcane. Agric Sci Digest 25(4): 244-247.

57. Roy P, Kabir M (2007) In vitro mass propagation of sugarcane (Saccharum officinarum L.) var Isd 32 through shoots tips and folded leaves culture. Biotechnology 6(4): 588-592.

58. Abdu S, Yahaya M, Shehu U (2012) In vitro regeneration of commercial sugarcane (Saccharum spp.) Cultivars in Nigeria. Journal of Life Science 6(7): 721-725.

59. Gopitha K, Bhavani L, Senthilmanickam J (2010) Effect of the different auxins and cytokinins in callus induction, shoot, root regeneration in sugarcane. International Journal of Pharmacology and Biotechnology Science 1(3): 1-7.

60. Molina V, Santos L, Lecona Guzmán L, Muñiz S, Méndez V, et al. (2005) Sugar cane buds as an efficient explant for plantlet regeneration. Biologia Plantarum 49(4): 481-485.

61. Mamun A, Sikdar H, Paul K, Mizanur M, Rahman D, et al. (2004) In vitro micropropagation of some important sugarcane varieties of Bangladish. Asian journal of plant sciences 3(6): 666-669 
62. Wongkaew P, Fletcher J (2004) Sugarcane white leaf phytoplasma in tissue culture: long-term maintenance transmission and oxytetracycline remission. Plant Cell Rep 23(6): 426-434.

63. Yadav S, Ahmad A, Lal M (2012) Effects of different auxins and cytokinins on in vitro multiplication and rooting of shoot cultures in sugarcane. Int J Biol Pharma Research 3(6): 814-818.

64. Sahoo D, Samantrai D, Rout G (2011) Rapid clonal propagation of Saccharum officinarum L Vars C0-6907 and CO-86249 and to assess the genetic uniformity through molecular markers. Plant Bios stems 145(2): 445-451.

65. Pathak S, Lal M, Tiwari k, Sharma L (2009) Effect of growth regulators on in vitro multiplication and rooting of shoot cultures in sugar cane. Sugar Technologyn 11(1): 86-88.

66. Dibax R, De Alcantara G, Bespalhok F, da Silva A (2013) Plant regeneration of sugarcane cv RB931003 and RB98710 from somatic embryos and acclimatization. Journal of Biotechnology and Biodiversity 2(3): 32-37.

67. Pawar V, Patil C, Jambhale M, Naik M (2002) Rapid multiplication of commercial sugarcane varieties through tissue culture. Indian sugar 52(3): 183-186.
68. Behera K, Sahoo S (2009) Rapid in vitro micro propagation of sugarcane (Saccharum officinarum L.) cv-Nayana through callus culture. Nature and Science 7(4): 1-10.

69. Yadav S, Ahmad A (2013) Standardization of callus culture techniques for efficient sugarcane micro propagation. Cibtech Journal of BioProtocols 2(2): 29-32.

70. Pandey R, Rastogi J, Sharma M, Singh R (2011) Technologies for cost reduction in sugarcane micro propagation. Africa Journal of Biotechnology 10(40): 7814-7819.

71. Ather A, Khan S, Rehman A, Nazir M (2009) Optimization of the protocols for callus induction, regeneration and acclimatization of sugarcane cv. thatta-10. Pakistan Journal Botany 41(2): 815-820.

72. Snyman S, Nkwanyana P, Watt M (2011) Alleviation of hyperhydricity of sugarcane plantlets produced in RITA ${ }^{\circledR}$ vessels and genotypic and phenotypic characterization of acclimated plants. South Africa Journal Botany 77(3): 685-692.

\section{Your next submission with Juniper Publishers will reach you the below assets}

- Quality Editorial service

- Swift Peer Review

- Reprints availability

- E-prints Service

- Manuscript Podcast for convenient understanding

- Global attainment for your research

- Manuscript accessibility in different formats

( Pdf, E-pub, Full Text, Audio)

- Unceasing customer service

Track the below URL for one-step submission

https://juniperpublishers.com/online-submission.php 